\title{
REGIONAL AND ACCESSIBILITY ANALYSIS OF THE BANKING SYSTEM AND THEIR IMPACTS TOWARD REGIONAL FINANCIAL INCLUSION IN INDONESIA
}

\author{
Irma Asyatun \\ Economic and Business Faculty, Brawijaya University, Indonesia. Email: irmaasyatun@gmail.com
}

\begin{abstract}
Financial inclusion has been widely discussed in the global level. The increased engagement in discussion of financial inclusion is inseparable from the implementation of policy priorities which are seemingly leaning towards improving financial inclusion to tackle poverty and growing inequality in a country. This article seeks to identify whether regional variables (income level, educational level, income inequality, population size and banking accessibility) are significant on influencing financial inclusion in Indonesia. This study proxied financial inclusion level by measuring the financial inclusion index using the method developed by Sarma in 2012. The research is conducted for 3 years, between 2012-2015. Employing the panel data estimation method, the results indicate that income level, educational level, and banking accessibility possess significant impact on financial inclusion in regional Indonesia.
\end{abstract}

Keywords: Financial Inclusion; Financial Inclusion Index; Banking Accessibility. JEL Classifications: G10; G20; G21.

Received : October 04, 2018

Revised : October 30, 2018

Accepted : November 29, 2018 


\section{INTRODUCTION}

Leyshon and Thrift (1995) state that financial inclusion is the antithesis of financial exclusion. The process of financial exclusion has made poor communities unable to reap benefits from the financial sector and has put them in disadvantage because of the lack of access, insurance, credit history, etc.

This situation is more visible in developing countries where inequality and poverty exclude the affected society from the financial system. As a developing country, Indonesia also encounters high level of financial exclusion from the formal financial sector.

As documented in the Inclusive Finance Booklet (2014), following the 2011 ASEAN Summit, Indonesia joined forces with international organisations such as the World Bank, Asian Development Bank, as well as G20, CGAP, AFI, APEC, ASEAN to produce a National Strategy of Inclusive Finance which later served as the country guidance for poverty alleviation strategy in Indonesia.

The data released by World Bank (2014) reveals that in 2014, 62\% of adult population worldwide already have bank accounts, while 2 million of the world population is considered as unbanked. In comparison with the financial inclusion rate in 2011 where only one-half (51\%) of the population were registered as account holders in banks and 2.5 million of unbanked people, we might say that the level of 'inclusive finance' has gotten a little better. Meanwhile, in Indonesia, roughly one-third of the total population received financial services, while about $64 \%$ still use the orthodox way of transacting; cash transaction (World Bank, 2014).

The low rate of financial inclusion in Indonesia is indicated with the highly concentrated distribution of financial services in several regions. The highly concentrated credit distribution is associated with the decrease in financial inclusion which might eventually hamper investments (Chauvet and Jacolin, 2017). This is evidenced by data describing the portion of credit distribution and the distribution of offices of Conventional Commercial Banks in Indonesia, as follows:

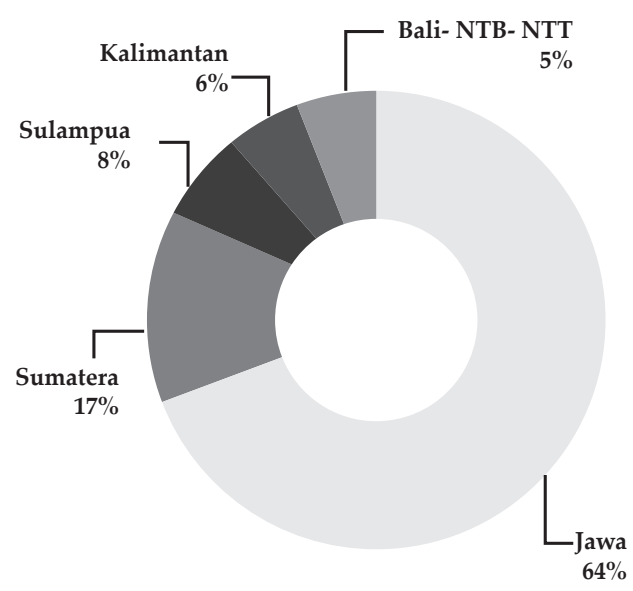

Source: Indonesia Banking Statistics, 2016

Figure 1. Distribution of Offices of Conventional Commercial Banks in Five Regions in Indonesia in 2016 


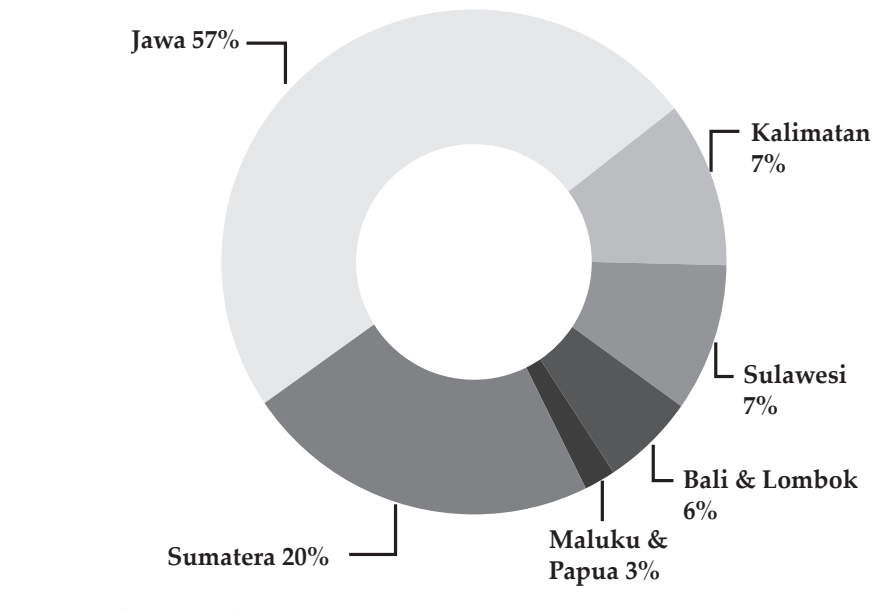

Source: Indonesia Banking Statistics, 2016

Figure 2. Distribution of MSMEs Lending Based on Regions in Indonesia in 2016

Whereas in terms of regional potential, each region has the potential advantages of distributing products and financial services equally. In Indonesia, the financial services are highly concentrated in Java Island, which prevents the country from achieving its highest potential of productivity in other regional area. As a result, the disparity of income and economic growth between regions become more apparent.

It is expected that financial inclusion program will allow every region to obtain the same opportunity on accessing financial services which will encourage poverty reduction, hence improving the welfare of the society.

\section{LITERATURE REVIEW}

\subsection{Concept of Financial Inclusion}

Before there was a term "financial inclusion", a large body of literatures initiate the discussion of financial inclusion. Leyshon and Trift (1995) defined financial exclusion as the antithesis of financial inclusion. Financial exclusion is described as a process of ensuring the existence of barriers in a social and individual group from accessing formal financial services.

An inclusive financial system is indispensable for various reasons. A World Bank Report (2014) stressed the importance of financial inclusion for social and economic development which indicates that controlled growth of access to financial services is a critical point that can reduce poverty rates, encourage inclusive and sustainable growth.

Furthermore, inclusion and access to financial services are two different issues. Financial inclusion is defined as the proportion of an individual or company that has used financial services. However, it is worth noting that not using financial services does not necessarily linked to financial exclusion, as there are people who opt not to use financial services despite the high accessibility they have. Reasons such as religious restrictions, reluctance to regulations and complex administration 
of financial institutions make individuals or companies reluctant to access financial services, especially in the formal financial sector such as banking.

Classification of behavior and conditions of the population towards financial services is presented in the figure below.

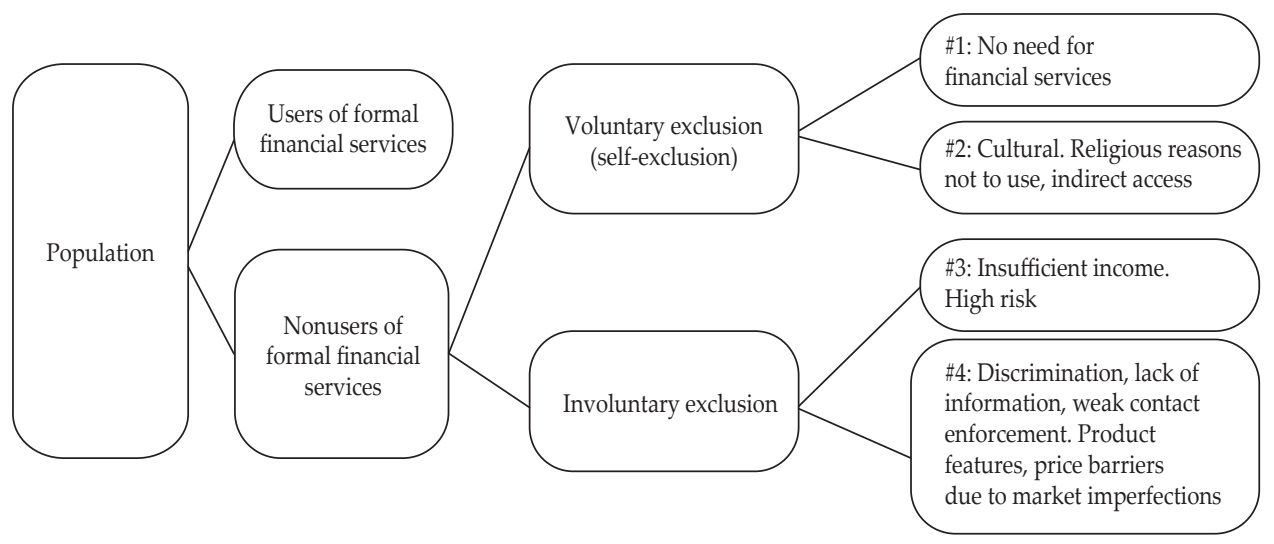

Source: World Bank, 2014

\section{Figure 3. The Utilisation and Access Towards Financial Services}

World Bank defines financial inclusion as a proportion of individual and company who utilises financial services. Sarma (2008), on the other hand, has a different interpretation of what financial inclusion means. She describes financial inclusion as a process of guaranteeing accessibility, availability, and usage of financial services for all of the society in an economy.

The present study follows the definition of Sarma (2008) where financial inclusion is defined as a process of guaranteeing accessibility, availability, and usage of financial services for all of the society in an economy. The understanding presented by Sarma illustrates the existence of dimensions that can shape the measurement of financial inclusion reflected in the value of financial inclusion index. In this study, the researcher attempts to calculate the financial inclusion index as a proxy for the value of financial inclusion in Indonesia for each province in the 2012-2015 period. Sarma (2008) summarized one concept relating to alternative measures of financial inclusion, namely the Financial Inclusion Index. This index itself is used to measure the inclusiveness of the financial system in a country. The calculation of the Financial Inclusion Index developed by Sarma is divided into three dimensions, namely:

1. Banking Penetration: Banking penetration is the main indicator of financial inclusion. High banking penetration is associated with higher financial inclusion rate, meaning the financial system is able to reach an even wider users. One of the indicators of banking penetration is the proportion of the population that owns a bank account.

2. Availability of Financial Services: In a condition where the financial system is inclusive, financial services are available to all people. This measure of availability is the number of outlets (network of bank offices, ATMs, etc.). The 
availability of financial services can also be seen from the number of networks of financial institutions or the number of ATMs (Automatic Teller Machines). It is undeniable that ATM has a very important role for banking services in serving the needs of the community. The ease of taking cash, depositing cash and being used for payments makes ATMs an absolute necessity for the community. With the existence of a network of bank offices and ATMs, the public will more easily reach financial services.

3. Use of Banking Services: There are numerous reasons underlying the low usage of banking services. To name a few, the distance of bank outlet from a person's accommodation or office, bad experiences with financial services are issues that negatively affect the usage of banking services. The use of financial service products in question can be in the form of credit, deposits, payments, transfers, etc. Appropriate indicator data to measure the dimensions, namely the volume of credit and deposits of adult population to the proportion to GDP.

\subsection{Measurement of Financial Inclusion Index}

The measurement of financial inclusion index applies the method by Sarma (2008) as follows.

(1) Measurement of Value from Each Dimension:

$$
d_{i}=w_{i} \frac{A_{i}-m_{i}}{M_{i}-m_{i}}
$$

Where:

$\left(W_{i}\right)$ = weighting for dimension $i$

$\left(A_{i}\right)=$ the actual value of dimension $i$

$\left(m_{i}\right)=$ lower limit (minimum value) of dimension $i$

$\left(M_{i}\right)=$ upper limit (maximum value) of dimension $i$

From the measurement using formula (1), it was found that $0 \leq\left(d_{i}\right) \leq\left(W_{i}\right)$, the higher di, the better the measurement of the success of a country or region in this dimension.

(2) Determination of Upper Bound Value $\left(M_{i}\right)$ and Lower Bound Value $\left(m_{i}\right)$ of each Dimension: Determination of the upper and lower bounds is very important in the process of normalizing the value of each dimension so that the value of each dimension $\left(d_{i}\right)$ will always be in the position of 0 and $w_{i}$

(3) Determination of the Weight of Each Dimension: Based on Sarma's method (2012), the weighting for each dimension is very difficult to determine, because the three dimensions that make up the financial inclusion index are dimensions of banking penetration, dimensions of availability of banking access and dimensions of use. All of these dimensions are equally important to support inclusive financial system services. Hence, the weights for all dimensions are 1.

(4) Calculation formula for Financial Inclusion Index: With point $A=(1,1,1)$, the final formula of IFI is as follows: 


$$
I F I=\frac{1}{2}\left[\frac{\sqrt{d_{1}^{2}+d_{2}^{2}+d_{3}^{2}}}{\sqrt{3}}+\left(1-\frac{\sqrt{\left(1-d_{1}\right)^{2}+\left(1-d_{2}\right)^{2}+\left(1-d_{3}\right)^{2}}}{\sqrt{3}}\right)\right]
$$

The IFI value ranged between 0 and 1 . If the IFI value of an area approaches 1 , then the level of financial inclusion in the area can be said to be high. Likewise, an IFI value close to 0 indicates the tendency of exclusion in financial services.

According to Sarma (2012), IFI values can be categorised into three groups. The first group is $0.6<I F I<1$. Regional groups with IFI values between 0.5 to 1 are categorized as High Inclusion areas. The second group is an area with IFI 0.3 $<$ IFI $<0.6$ categorized in Medium financial inclusion. The last category is the low group, where the value of the financial inclusion index of an area is under 0.3.

\subsection{Previous Studies}

Sarma and Pais (2011) conducted a study on financial inclusion and development by analysing the conditions between regions. Using Sarma's (2008) financial inclusion index, this study identifies significant factors related to financial inclusion. Socio-economic factors such as human development index, income, income inequality and literacy, as well as physical infrastructure for connecting and sharing information. In addition, other variables from the banking sector such as NPA and CAR were also examined to see their effects on financial inclusion. We utilise the data from 49 countries in the year of 2004. Having analysed the data using regression methods, we found that human development is highly associated with financial inclusion. Furthermore, income is positively related to financial inclusion and physical infrastructure. Meanwhile, the NPA and CAR are negatively correlated with financial inclusion.

Chakravarty and Pal (2013) re-examined the financial inclusion approach in India. In the article, they first constructed a measurement of financial inclusion from the banking service supply side which consisted of six indicators namely geographic and demographic penetration, number of deposit and credit accounts per 1,000 people, ratio of deposits per income and credit ratio per income. The study continued by estimating the impact on priority policies in the banking sector in India during 1972-2009, using the data panel econometric technique to analyze the problem (GMM method). The results showed that social banking policy had an important role in accelerating financial inclusion between regions in India during 1977-1990. Moreover, a policy shift that is more supportive of financial market sector reform does not have too good an impact on financial inclusion. In this paper, it is identified that the geography penetration of banking and credit availability are two policy targets for accelerating financial inclusion in India. Financial inclusion is proxied by financial inclusion index data.

Demirgüc-Kunt and Klapper (2013) examined the alternative measurement of financial inclusion using data of financial services in 148 countries in the year of 2011. The data was acquired from the World Bank's Global Findex. The study examines the individual character and country-related character associated with three indicators of financial inclusion; ownership of a formal account, bank savings 
account, use of bank credit. The results show that income differences between countries and between individuals have enormous impact on the level of financial inclusion in a country.

\subsection{Theoretical Framework and Hypothesis}

The theoretical framework of this study can be illustrated as follows (see Figure 4):

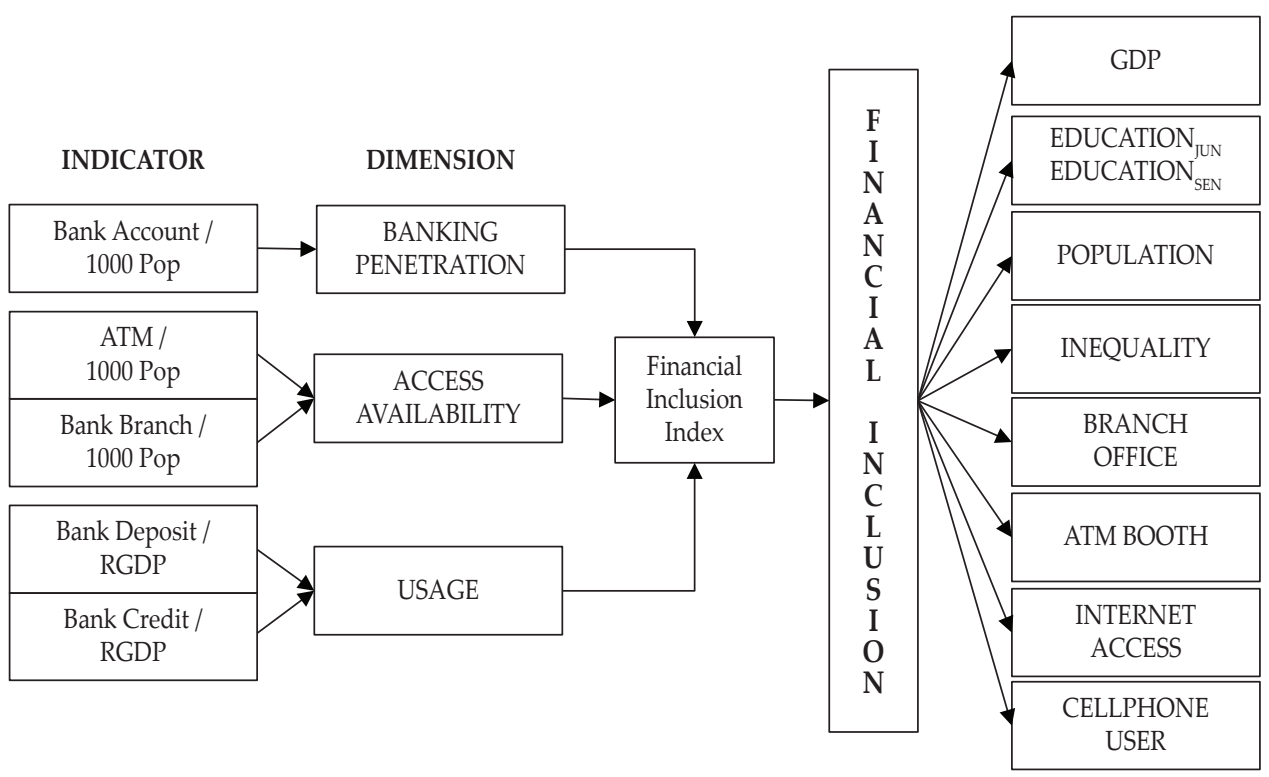

Source: Author, 2018

Figure 4. Theoretical Framework

Based on the theoretical framework above, this study seeks to identify whether regional variables (GDP per capita, education level (junior and senior high and above), the level of income inequality and the adult population and the level of banking accessibility, bank branch offices, ATM outlets, internet users and mobile phones) ameliorate financial inclusion in the Indonesian Regional Region. The research hypotheses are as follows:

1. Income level positively affects financial inclusion in Indonesia.

2. Educational level positively affects financial inclusion in Indonesia.

3. A country population (considered as the market share of the banking industry) positively affects financial inclusion in Indonesia

4. Income inequality negatively affects financial inclusion in Indonesia.

5. The bank branch office network variable in an area positively affects financial inclusion in Indonesia.

6. The number of ATMs positively affects financial inclusion in Indonesia

7. Internet access positively affects financial inclusion in Indonesia.

8. Cell phone user positively affects financial inclusion in Indonesia 


\section{METHODOLOGY}

\subsection{Data}

This is a quantitative study with the secondary data acquired from official government websites such as Bank Indonesia (www.bi.go.id), BPS (www.bps.go.id) and the Financial Services Authority (www.ojk.go.id). This research also explored various literatures related to financial inclusion in several countries or groups of countries.

\subsection{Research Variables, Operational Definition and Data Source}

As the dependent variable of the present study, the financial inclusion rate must be calculated in advance in order to obtain the proxy value of the variable. In this study, the proxy of financial inclusion variable is the financial inclusion index value calculated from three dimensions.

In this study, financial inclusion index indicators will be calculated based on the values of three dimensions, as follows:

Table 1.

Measurement of Indicators of Financial Inclusion Index

\begin{tabular}{|c|c|c|c|c|}
\hline No & Dimension & Indicator & Measurement & Source \\
\hline 1 & $\begin{array}{l}\text { (d1) Bank } \\
\text { Penetration }\end{array}$ & $\begin{array}{c}\text { Conventional } \\
\text { Commercial Bank } \\
\text { Account }\end{array}$ & $=\frac{\text { Number of Bank Accounts }(\text { year } t)}{\text { Population Size }(\text { year } t)} \times 1000$ & www.ojk.go.id \\
\hline \multirow[t]{2}{*}{2} & $\begin{array}{l}\text { (d2) } \\
\text { Availability }\end{array}$ & $\begin{array}{l}\text { Office Network } \\
\text { of Conventional } \\
\text { Commercial Bank }\end{array}$ & $=\frac{\text { Number of Bank Offices }(\text { year } t)}{\text { Population Size }(\text { year } t)} \times 1000$ & www.bi.go.id \\
\hline & & $\begin{array}{l}\text { Total ATM outlet } \\
\text { of Conventional } \\
\text { Commercial Bank }\end{array}$ & $=\frac{\text { Number of Bank Offices }(\text { year } t)}{\text { Number of ATM outlet }(\text { year } t)} \times 100,000$ & www.ojk.go.id \\
\hline \multirow[t]{2}{*}{3} & (d3) Usage & $\begin{array}{l}\text { Amounts of Loan } \\
\text { of Conventional } \\
\text { Commercial Bank in } \\
\text { the private sectors }\end{array}$ & $=\frac{\text { Total of private loan disbursed }}{\text { Real Gross Domestic Regional Product }} \times 100 \%$ & www.bi.go.id \\
\hline & & $\begin{array}{c}\text { Amount of } \\
\text { Deposit Funds } \\
\text { of Conventional } \\
\text { Commercial Bank }\end{array}$ & $=\frac{\text { Total of deposit funds }}{\text { Real Gross Domestic Regional Product }} \times 100 \%$ & www.bi.go.id \\
\hline
\end{tabular}

Table 2 summarises the explanation of labeling in the equation formed by this study, the variables used in the research and the information sources of the data obtained. 
Table 2.

Operational Definition of Research Variables

\begin{tabular}{|c|c|c|c|c|}
\hline No & Label & Variable & Definition & Source \\
\hline 1 & FI & Financial Inclusion & $\begin{array}{l}\text { Data on financial inclusion index } \\
\text { calculation using the Sarma method. } \\
\text { Where the calculation of the } \\
\text { financial inclusion index consists } \\
\text { of three-dimensional indicators, } \\
\text { namely banking penetration, } \\
\text { availability of access and use of } \\
\text { banking product services }\end{array}$ & $\begin{array}{c}\text { The author's calculation } \\
\text { using the method } \\
\text { developed by Sarma } \\
\text { (2012). }\end{array}$ \\
\hline 2 & INCOME & $\begin{array}{l}\text { Real Per Capita } \\
\text { Income }\end{array}$ & $\begin{array}{l}\text { The Real Per Capita Income of the } \\
\text { Community (Rp. (ADHK year 2010). }\end{array}$ & www.bps.go.id \\
\hline 3 & EDU & Educational Level & $\begin{array}{l}\text { The highest education level } \\
\text { achieved by those aged } 16-30 \text { is the } \\
\text { highest level of education that has } \\
\text { been completed by someone who is } \\
\text { no longer attending school. Includes } \\
\text { Percentage of junior high school } \\
\text { and senior high school level and } \\
\text { above. }(\%)\end{array}$ & www.bps.go.id \\
\hline 4 & POP & Population Size & $\begin{array}{c}\text { Percentage of development of adult } \\
\text { population (> 15 years old) }(\%)\end{array}$ & www.bps.go.id \\
\hline 5 & INEQUALITY & Gini Coefficient & Gini coefficient & www.bps.go.id \\
\hline 6 & $\mathrm{BRCH}^{*}$ & $\begin{array}{c}\text { Conventional } \\
\text { Commercial Bank } \\
\text { Branch Office } \\
\text { Network }\end{array}$ & $\begin{array}{l}\text { Conventional Commercial Bank } \\
\text { Branch Office per } 1000 \text { km2 }\end{array}$ & www.bi.go.id \\
\hline 7 & $\mathrm{ATM}^{* *}$ & $\begin{array}{c}\text { Conventional } \\
\text { Commercial Bank } \\
\text { ATM Outlet }\end{array}$ & $\begin{array}{l}\text { Conventional Commercial Bank } \\
\text { ATM outlets per } 1000 \mathrm{~km} 2\end{array}$ & www.ojk.go.id \\
\hline 8 & INTRNT & Internet Users & $\begin{array}{l}\text { Percentage of Population Aged } 5 \\
\text { Years and Over Who Previously } \\
\text { Accessed the Internet in the Last } 3 \\
\text { Months (\%) }\end{array}$ & www.bi.go.id \\
\hline 9 & PHONE & Cellphone users & $\begin{array}{l}\text { Percentage of Population Owning / } \\
\text { Mastering Cellular Phones (\%) }\end{array}$ & www.bps.go.id \\
\hline
\end{tabular}

Source: Data processed by author, 2018

Note:

*BRCH $=\frac{\text { Number of of fices of Conventional Commercial Banks (year t in province } i)}{\text { Landmass }(\text { year } 2016 \text { in province } i)} \times 1000 \mathrm{Km} 2$

$* * A T M=\frac{\text { Number of ATM Outlet of Conventional Commercial Bank }(\text { year } t \text { in province } i)}{\text { Landmass }(\text { year } 2016 \text { in province } i)} \times 1000 \mathrm{Km} 2$

\subsection{Model of Analysis}

In this study, the model of analysis used is the panel data analysis model. In general, the equation can be written as follows:

$$
\begin{aligned}
\mathrm{FI}_{\mathrm{it}}=\beta_{0} & +\beta_{1} \mathrm{INCOME}_{\mathrm{it}}+\beta_{2} \mathrm{EDU}_{\mathrm{SMPit}}+\beta_{2} \mathrm{EDU}_{\mathrm{SMAit}}+\beta_{4} \mathrm{POP}_{\mathrm{it}} \\
& -\beta_{5} \text { INEQUALITY }_{\mathrm{it}}+\beta_{6} \mathrm{BRCH}_{\mathrm{it}}+\mu_{\mathrm{it}}
\end{aligned}
$$




$$
\begin{aligned}
& \mathrm{FI}_{\mathrm{it}}=\beta_{0}+\beta_{1} \mathrm{INCOME}_{i \mathrm{i}}+\beta_{2} \mathrm{EDU}_{\text {SMPit }}+\beta_{2} \mathrm{EDU}_{\text {SMAit }}+\beta_{4} \mathrm{POP}_{\text {it }} \\
& -\beta_{5} \text {INEQUALITY }_{\mathrm{it}}+\beta_{7} \text { ATM }_{\mathrm{it}}+\mu_{\mathrm{it}} \\
& \mathrm{FI}_{\mathrm{it}}=\beta_{0}+\beta_{1} \mathrm{INCOME}_{\mathrm{it}}+\beta_{2} \mathrm{EDU}_{\mathrm{SMPit}}+\beta_{2} \mathrm{EDU}_{\text {SMAit }}+\beta_{4} \mathrm{POP}_{\text {it }} \\
& -\beta_{5} \text { INEQUALITY }_{\mathrm{it}}+\beta_{8} \text { INTRNT }_{\mathrm{it}}+\mu_{\mathrm{it}} \\
& \mathrm{FI}_{\mathrm{it}}=\beta_{0}+\beta_{1} \mathrm{INCOME}_{\mathrm{it}}+\beta_{2} \mathrm{EDU}_{\text {SMPit }}+\beta_{2} \mathrm{EDU}_{\text {SMAit }}+\beta_{4} \mathrm{POP}_{\mathrm{it}} \\
& -\beta_{5} \text { INEQUALITY }_{\text {it }}+\beta_{9} \text { PHONE }_{\text {it }}+\mu_{\text {it }}
\end{aligned}
$$

\subsection{Method}

1. Selection of Panel Data Model

In panel data regression analysis, there are three methods which can be used to estimate the panel data regression model, namely Pooled Least Square (PLS) method, Fixed Effect method (FEM), and Random Model (REM).

a. Likelihood Test (Redundant Fixed Effects Tests), The test is used to determine the most appropriate model between the PLS and fixed effect models.

Likelihood test hypothesis;

$\mathrm{H}_{0}$ : Pooled model is better suited

$\mathrm{H}_{\mathrm{a}}$ : Fixed effect model is better suited

b. Haussman Test. The test is utilised to choose between the two panel data models; fixed effect and random effect. The Haussman test analysis is as follows.

$\mathrm{H}_{0}$ : Random effect model is better suited

$\mathrm{H}_{\mathrm{a}}$ : Fixed effect model is better suited

Basis of Decision Making:

1. If the chi-square probability value $<$ alfa $(0.05), \mathrm{H}_{0}$ is rejected and $\mathrm{H}_{\mathrm{a}}$ is accepted

2. If the chi-square probability value $>$ alfa $(0.05), H_{0}$ is accepted and $H_{a}$ is rejected

2. Classic Assumption Tests

a. Normality Test

The assumption of normality test is every $\mu_{i}$ (error) can be distributed normally, or average $\mathrm{E}\left(\mu_{i}\right)=\delta^{2}$, or it can be written down as $\mu_{i}-\mathrm{N}\left(0, \delta^{2}\right)$. Data normality testing can be seen from the jarque-fall probability value, where the hypothesis is as follows:

$\mathrm{H}_{0}$ : residual is normally distributed

$\mathrm{H}_{\mathrm{a}}$ : residual is not normally distributed

Basis of Decision Making:

1. If the chi-square probability value $<$ alfa $(0.05), \mathrm{H}_{0}$ is rejected and $\mathrm{H}_{\mathrm{a}}$ is accepted;

2. If the chi-square probability value $>$ alfa $(0.05), \mathrm{H}_{0}$ is accepted and $\mathrm{H}_{\mathrm{a}}$ is rejected.

b. Multicollinearity

It is a problem where data has a "perfect" linear relationship between its independent variables in a regression modeling. For regression variable 
$k$ involving explanatory variables $X_{1}, X_{2}, X_{3^{\prime}}, X_{n} \ldots$ (where $X_{1}=1$ for all observations follows the intercept factor), it is assumed that there is a "perfect" linear relationship if the following conditions occur:

$$
\lambda_{1} X_{1}+\lambda_{2} X_{2}+\lambda_{3} X_{3}+\ldots . \lambda_{n} X_{n}=0
$$

c. Autocorrelation

Autocorrelation is defined as the correlation between lags of a particular row and its own. Or simply it can be said that autocorrelation is a problem of assumption of calcifications where there is a correlation between observations for different periods. Or it is also a condition where the nature of the residual regression is interrelated between one observation (i) with another observation $\left(j^{\text {th }}\right)$ (Wahyudi, 2016). The formula can be written follows: $\mathrm{E}\left(\varepsilon_{\mathrm{i}}, \varepsilon_{\mathrm{j}}\right) \neq 0 ; \mathrm{i} \neq \mathrm{j}$. Autocorrelation can be detected by looking at the Durbin-Watson value. If:

$0<\mathrm{d}<\mathrm{dL}$ : there is a positive autocorrelation

$\mathrm{dL}<\mathrm{dW}<\mathrm{dU}$ : the area is uncertain

$\mathrm{dU}<\mathrm{d}<4-\mathrm{dU}$ : there is no autocorrelation

$4-\mathrm{dU}<\mathrm{d}<4-\mathrm{dL}$ : the area is uncertain

$4-\mathrm{dL}<\mathrm{d}<4$ : there is a negative autocorrelation

d. Heteroscedasticity

The problem arising from the $\mu$ variance value is $\sigma^{2}$, which shows the variance error value varies from one observation to another, or in other words the variance error value is not constant. In general, heteroscedasticity can be described as follows: $\mathrm{E}\left(\mu_{\mathrm{it}}{ }^{2}\right)=\sigma_{\mathrm{it}}{ }^{2}$

3. Model Feasibility Testing

a. T-statistical test: Aims to see the effect of independent variables on the dependent variable. Influence can be seen by comparing t-count and $\mathrm{t}$-table or seeing the significance of each $\mathrm{t}$-count. If the probability value is less than 5\% alpha, there is an influence of the independent variable on the dependent variable.

b. F-statistical test: $\mathrm{F}$ test is useful for testing the regression coefficients (slope) together, or to ensure the feasibility of the model that interprets the independent variables on the dependent variable.

c. Determination Coefficient $\left(\mathrm{R}^{2}\right)$ : The determination test aims to see how much the independent variable can explain the dependent variable (fit model), where the $R^{2}$ value is between 0 and 1 . If the $R^{2}$ value approaches 1 , the independent variable strength in explaining the dependent variable is increasingly high.

\section{RESULTS AND FINDINGS}

\subsection{Results}

\section{Financial Inclusion Index}

By using the calculation method of financial inclusion index developed by Sarma (2012), this study has successfully calculated the financial inclusion index of all provinces in Indonesia. The findings demonstrate that DKI Jakarta is the 
province with the highest financial inclusion index. With an average financial inclusion index value of 1, Jakarta has an absolute value of financial inclusion index.

In general, an explanation of the financial inclusion index can be grouped into 3 provincial groups. Where the provincial group that has the financial inclusion index value $>0.6$ belongs to the region which possesses high financial inclusion. The provinces in this group include DKI Jakarta, Bali, DI Yogyakarta, Riau Island, East Kalimantan, North Sumatra, South Kalimantan, North Sulawesi, Banten, South Sulawesi, West Papua, and in the last position there is the province of Papua

The middle group consists of provinces with financial inclusion index in the range of 0.3 to less than 0.6. Among the provinces included in this category are; West Kalimantan, West Java, East Java, Maluku, West Sumatera, Bangka Belitung, Bengkulu, Aceh, NTT, North Maluku, Central Java, South Sumatera, Central Kalimantan, Southeast Sulawesi, Riau, Jambi, Central Sulawesi, Gorontalo, NTB, West Sulawesi, Lampung.

The third category is provinces with financial inclusion index below 0.3. It was evident from the results that none of the provinces in Indonesia are in the low financial inclusion index category. According to the national literacy survey and financial inclusion index in Indonesia conducted by the OJK in 2016, the financial inclusion index of Indonesia in 2013 soared from 59.7\% to 67.8\% This is in line with the results of the authors' calculations, where on the average most of the financial inclusion levels in the Indonesian provinces are in the category of High financial Inclusion with an average of 0.640 or $64 \%$ for the 12 provinces of the High Index Inclusion category. The remaining 21 provinces in Indonesia are included in the Medium Financial Inclusion Index category with an average financial inclusion index of 0.457 or $45.7 \%$.

The average financial inclusion index for all provinces in 2013 was 58.7\%. The figure is slightly differ from the data of financial inclusion index by OJK which reported that the financial inclusion index of Indonesia in 2013 is $59.7 \%$. Limitations on data collection made the study unable to calculate the financial inclusion index for 2016.

Nevertheless, when looking at the pattern of calculation results of the financial inclusion index per province, it is evident that there is a continuous improvement on the country financial inclusion index from year to year. High financial inclusion index in an area shows that financial sector activities ranging from affordability of services, availability of access to the use of financial products have satisfied the public demands.

Contrary to indications of financial inclusion in the Papua region categorized as high financial inclusion based on the results of calculations of macro banking data. Where each indicator of financial inclusion is calculated based on the number of adult populations in an area. Based on this data, the Papua region has a low adult population while data on the number of infrastructure and financial products tend to be higher than the population. This has become a weakness in using banking macro data where there is a double account indication, the concentration of financial product distribution still cannot be accommodated in the calculation of financial inclusion index in this study. Summary of the results of the calculation of the financial inclusion index for each province in Indonesia is as follows: 
Table 3.

Results of Calculation of Financial Inclusion Index in the Provincial Level in Indonesia (2012-2015)

\begin{tabular}{|c|c|c|c|c|c|c|c|}
\hline \multirow[b]{2}{*}{ NO } & \multirow[b]{2}{*}{ PROVINCE } & \multicolumn{5}{|c|}{ IFI $w(1,1,1)$} & \multirow[b]{2}{*}{ Rank } \\
\hline & & 2012 & 2013 & 2014 & 2015 & $\begin{array}{c}\text { Average of } \\
\text { Financial } \\
\text { Inclusion } \\
\text { Index }\end{array}$ & \\
\hline 1 & $\mathrm{ACEH}$ & 0,431 & 0,527 & 0,572 & 0,627 & 0,539 & 20 \\
\hline 2 & SUMUT & 0,581 & 0,671 & 0,729 & 0,757 & 0,685 & 6 \\
\hline 3 & SUMBAR & 0,471 & 0,549 & 0,581 & 0,620 & 0,555 & 17 \\
\hline 4 & RIAU & 0,403 & 0,476 & 0,523 & 0,551 & 0,488 & 27 \\
\hline 5 & JAMBI & 0,389 & 0,478 & 0,518 & 0,552 & 0,484 & 28 \\
\hline 6 & SUMSEL & 0,434 & 0,508 & 0,543 & 0,568 & 0,513 & 24 \\
\hline 7 & BENGKULU & 0,454 & 0,524 & 0,568 & 0,620 & 0,542 & 19 \\
\hline 8 & LAMPUNG & 0,300 & 0,365 & 0,387 & 0,418 & 0,367 & 33 \\
\hline 9 & KEPBANGKA & 0,459 & 0,536 & 0,579 & 0,615 & 0,547 & 18 \\
\hline 10 & KEPRIAU & 0,758 & 0,818 & 0,812 & 0,809 & 0,799 & 4 \\
\hline 11 & DKI & 1 & 1 & 1 & 1 & 1,000 & 1 \\
\hline 12 & JABAR & 0,476 & 0,570 & 0,623 & 0,652 & 0,580 & 14 \\
\hline 13 & JATENG & 0,419 & 0,505 & 0,553 & 0,584 & 0,515 & 23 \\
\hline 14 & DIY & 0,733 & 0,831 & 0,886 & 0,915 & 0,842 & 3 \\
\hline 15 & JATIM & 0,461 & 0,558 & 0,616 & 0,647 & 0,570 & 15 \\
\hline 16 & BANTEN & 0,556 & 0,664 & 0,727 & 0,754 & 0,675 & 9 \\
\hline 17 & BALI & 0,791 & 0,874 & 0,889 & 0,898 & 0,863 & 2 \\
\hline 18 & NTB & 0,362 & 0,447 & 0,513 & 0,535 & 0,464 & 31 \\
\hline 19 & NTT & 0,418 & 0,506 & 0,551 & 0,605 & 0,520 & 21 \\
\hline 20 & KALBAR & 0,484 & 0,576 & 0,627 & 0,686 & 0,593 & 13 \\
\hline 21 & KALTENG & 0,418 & 0,492 & 0,527 & 0,555 & 0,498 & 25 \\
\hline 22 & KALSEL & 0,561 & 0,666 & 0,726 & 0,776 & 0,682 & 7 \\
\hline 23 & KALTIM & 0,618 & 0,697 & 0,755 & 0,751 & 0,705 & 5 \\
\hline 24 & SULUT & 0,513 & 0,677 & 0,746 & 0,789 & 0,681 & 8 \\
\hline 25 & SULTENG & 0,443 & 0,451 & 0,490 & 0,534 & 0,480 & 29 \\
\hline 26 & SULSEL & 0,527 & 0,636 & 0,692 & 0,740 & 0,649 & 10 \\
\hline 27 & SULTENGGARA & 0,464 & 0,469 & 0,489 & 0,531 & 0,488 & 26 \\
\hline 28 & GORONTALO & 0,365 & 0,466 & 0,490 & 0,541 & 0,465 & 30 \\
\hline 29 & SULBAR & 0,387 & 0,426 & 0,340 & 0,366 & 0,380 & 32 \\
\hline 30 & MALUKU & 0,452 & 0,535 & 0,615 & 0,663 & 0,566 & 16 \\
\hline 31 & MALUKUUTR & 0,443 & 0,528 & 0,522 & 0,578 & 0,518 & 22 \\
\hline 32 & PAPUABRT & 0,545 & 0,655 & 0,617 & 0,638 & 0,614 & 11 \\
\hline \multirow[t]{2}{*}{33} & PAPUA & 0,520 & 0,604 & 0,638 & 0,686 & 0,612 & 12 \\
\hline & AVERAGE & 0,504 & 0,584 & 0,619 & 0,653 & & \\
\hline
\end{tabular}




\section{Model Selection}

The test results of Model Selection can be seen in Table 4 below, which conclude that the best model is Fixed Effect Model for all equations.

Table 4.

Test Results of Model Selection

\begin{tabular}{|c|c|c|c|c|c|}
\hline \multirow{2}{*}{$\begin{array}{l}\text { SELECTING } \\
\text { THE BEST } \\
\text { MODEL }\end{array}$} & & \multicolumn{4}{|c|}{ MODEL } \\
\hline & & 1 & 2 & 3 & 4 \\
\hline \multirow[t]{3}{*}{$\begin{array}{l}\text { LIKELIHOOD } \\
\text { RATIO }\end{array}$} & $\begin{array}{l}\text { Cross-section } \\
\text { Chi-square }\end{array}$ & 257.427 & 268.0833 & 221.1576 & 260.7872 \\
\hline & p-value & 0 & 0 & 0 & 0 \\
\hline & Conclusion & FIXED EFFECT & FIXED EFFECT & FIXED EFFECT & FIXED EFFECT \\
\hline \multirow[t]{3}{*}{ HAUSMAN TEST } & Chi-sq. statistics & 79.4056 & 90.45605 & 22.3942 & 26.35673 \\
\hline & p-value & 0 & 0 & 0.0001 & 0.0002 \\
\hline & Conclusion & FIXED EFFECT & FIXED EFFECT & FIXED EFFECT & FIXED EFFECT \\
\hline
\end{tabular}

From the results of selecting the most appropriate model, all the equations used in this study are employing the fixed effect model. The p-value of the Chi-square Cross-section is less than alpha 0.05 , hence $\mathrm{H}_{0}$ is rejected, which means that the fixed effect model is better than the common effect model. Furthermore, from the comparison between the fixed effect model and random effect and hausman test, the p-value acquired is less than alpha 0.05 , which strengthen the decision to employ the fixed effect model.

\section{Test Results of Classic Assumption}

The results in Table 5 indicate the existence of problems in the classic assumption of the formation of research models. Thus, the initial model is unable to progress to further analysis. The modeling will be fixed first to produce an estimation which is BLUE in character and is free from the problem of classical assumptions.

Table 5.

Summary of Classic Assumption Test Results

\begin{tabular}{lcccc}
\hline CLASSIC ASSUMPTION & \multicolumn{5}{c}{ MODEL } \\
\cline { 2 - 5 } TEST & $\mathbf{1}$ & $\mathbf{2}$ & $\mathbf{3}$ & $\mathbf{4}$ \\
\hline NORMALITY TEST & Normal & Normal & Normal & Normal \\
AUTOCORRELATION & - & - & - & - \\
MULTICOLLINEARITY & No & No & No & No \\
HETEROSCEDASTICITY & Yes & Yes & Yes & Yes \\
\hline
\end{tabular}

Source: Eviews, 2018

The Glejser test results provide evidence of the occurrence of heteroscedasticity problems in the equations. For this reason, the handling of the data regression for all equations is done using the GLS method, or more specifically the White 
Heteroscedasticity Consistent Coefficient Covariance method. The method is used to make corrections to the standard error of the regression coefficient, (Wahyudi, 2016).

\section{Results of Panel Data}

The results of panel data regressions of all 4 (four) equations can be seen in Table 6 below.

Table 6.

Summary of Results of Panel Data Estimation

\begin{tabular}{lcccc}
\hline \multirow{2}{*}{$\begin{array}{l}\text { Independent } \\
\text { variables }\end{array}$} & $\begin{array}{c}\mathbf{- 1} \\
\text { coeff. } \\
\text { (p-values) }\end{array}$ & $\begin{array}{c}\text { log IFI W(1,1,1) } \\
\text { coeff. } \\
\text { (p-values) }\end{array}$ & $\begin{array}{c}-\mathbf{3} \\
\text { coeff. } \\
\text { (p-values) }\end{array}$ & $\begin{array}{c}\text { - } \\
\text { coeff. } \\
\text { (p-values) }\end{array}$ \\
\hline C & -13.79354 & -10.59018 & -11.76515 & -7.530754 \\
$\log ($ GDP per Capita) & $1.256454(0.000)^{* * *}$ & $0.939014(0.0001)^{* * *}$ & $1.060629(0.0017)^{* * * *}$ & $0.574062(0.0296)^{* *}$ \\
EDUSMP & $0.000765(0.3561)$ & $0.001066(0.319)$ & $0.000875(0.2772)$ & $0.000932(0.6751)$ \\
EDUSMA & $0.49628(0.0487)^{* * *}$ & $0.541577(0.0162)^{* *}$ & $0.618256(0.0186)^{* *}$ & $0.668411(0.000)^{* * *}$ \\
INEQUALIY & $-0.582178(0.2218)$ & $-0.522695(0.2557)$ & $-0.261982(0.5919)$ & $-0.051629(0.8999)$ \\
POP & $-0.36617(0.1037)$ & $-0.133777(0.5719)$ & $0.12083(0.7628)$ & $0.419526(0.4554)$ \\
log(BRCH) & $0.446426(0.0428)^{* *}$ & - & - & - \\
$\log ($ ATM) & - & $0.325337(0.0004)^{* * *}$ & - & - \\
INTERNET ACCESS & - & - & $0.008862(0.0948)^{*}$ & - \\
USAGE & - & - & - & $0.015859(0.0001)^{* * * *}$ \\
CELLPHONE USAGE & - & 0.938832 & 0.931276 & 0.939059 \\
$R^{\wedge} 2$ & 0.932436 & 0.913838 & 0.903195 & 0.914159 \\
ADJUSTED R^2 & 0.90483 & 37.56317 & 33.16401 & 37.71246 \\
F-TES & 33.77578 & 0 & 0 & 0 \\
PROB F STAT & 0 & 1.323896 & 1.412974 & 1.573927 \\
DURBIN WATSON & 1.293829 & & &
\end{tabular}

Source: Author, 2018

Notes: * Significant at $10 \%$ level; ${ }^{* *}$ Significant at $5 \%$ level; ${ }^{* * *}$ Significant at $1 \%$ level

\subsection{Discussions}

\subsubsection{Test Results}

The F-Test Hypothesis Test Results as presented in Table 6 concerning the regression results of panel data with fixed effect model, show that the probability value of the F-test for all equations is 0.000 . Since the F-Test result is smaller than alpha $0.05, \mathrm{H}_{0}$ is rejected and $\mathrm{H}_{\mathrm{a}}$ is accepted. The acceptance of $\mathrm{H}_{\mathrm{a}}$ means that income level, educational level, number of population, income inequality, number of bank branches (1), number of ATM outlets (2), number of internet users (3) and development of number of cellphone users (4) have a simultaneous and significant influence on financial inclusion.

The Determination Coefficient Test Results $\left(\right.$ Adj. $\left.R^{2}\right)$, represented by the value of adjusted $\mathrm{R}^{2}$ of all the outputs of the panel data regression equation, is above $90 \%$. Adjusted $\mathrm{R}^{2}$ value of each equation is $0.90483,0.913838,0.903195,0.914159$. 
These mean that $90.48 \%$ of the total variation of financial inclusion value can be explained by the following variables: income level, educational level, number of population, income inequality level, and number of bank branches. The remaining $9.52 \%$ is explained by the error variable.

In equation (2), the adjusted $\mathrm{R}^{2}$ value is 0.9138 , which means that $91.38 \%$ of financial inclusion rate can be explained by income level, educational level, population size, income inequality level and number of ATM outlets. Meanwhile, the other $8.62 \%$ is explained by the error variable.

In equation (3), the adjusted $\mathrm{R}^{2}$ value is 0.9031 , which means that around $90.31 \%$ of the total variation of financial inclusion can be explained by income level, educational level, population size, income inequality and internet users. The remaining $9.69 \%$ is explained by the error variable.

Adjusted $\mathrm{R}^{2}$ value for equation (4) is equal to 0.9247 , which means that around $92.47 \%$ of the variation of financial inclusion can be explained by income level, educational level, population size, income inequality level and number of cellphone users. The remaining amount of approximately $7.53 \%$ is explained by the error variable.

\subsubsection{Main Results}

The main results of panel data analysis (T-test results) can be divided into several section as follows.

\section{a) GDP Per Capita Variable}

The probability value ( $\mathrm{t}$ statistics) of the per capita income variable from each equation is $0.000,0.0001,0.00017$ and 0.0296 . With an alpha value of $5 \%$, the GDP variable has a significant influence in financial inclusion in Indonesia. The higher the GDP value, the higher the level of financial inclusion in Indonesia.

Higher income per capita will reduce the risk profile that can hinder the public from accessing financial services. Consequently, there is a greater opportunity for high-income people to access financial services. In addition to the higher income per capita of the community, the opportunity of saving and investment in formal financial institutions is also increasing.

An increase in a society income per capita will encourage the increase in financial inclusion from the demand-side, which means that if the ability of the community increases, the demand for financial products will also increase along with the needs of the community, both in terms of transactions, payments and other matters related to services offered by formal financial institutions especially conventional public banking in Indonesia.

This is also supported by the results of the Financial Inclusion In Asia Survey conducted by the Asian Development Bank (2014), which clearly states that accessing financial services is very unlikely without increasing the capabilities of individuals and companies to reach higher income levels. Thus, increasing financial inclusion is closely associated with the direct impact of individual capability and the financial literacy of individuals.

According to the World Bank Report (2010) of financial inclusion in Indonesia, the main rationale as to why Indonesian people unable to access financial 
services such as deposit is because $70 \%$ of them do not have enough money. The Government then designed a new policy aiming at increasing individual capabilities such as increasing the income level of the society so that they will be able to use the financial facilities provided. In addition to basic products such as savings, the results of the world bank survey also seen found that rougly one-fifth of the people who were rejected in applying for credit by banks were due to their low income level.

The findings of World Bank (2010) is supported by several previous studies which say that income level significantly affects financial inclusion of developing countries in Asia (Park and Mercado, 2015). Similarly, a research conducted by Demirguck-kunt et al. (2011) found that per capita income is positively correlated with financial inclusion. The higher the level of income per capita the community, the higher the rate of financial inclusion

b) Variable level of education (EDUSMP and EDUSMA) In addition to per capita income, this study also produced an analysis of the influence of junior (EDUSMP) and senior (EDUSMA) high school education levels completed by the adult population. The t-statistics probability value of the EDUSMP variable in each equation is $0.3561,0.319,0.2772$, and 0.1223 . With the probability value from all equations being over 0.05 , the EDUSMP variable does not significantly influence the level of financial inclusion in Indonesia.

On the other hand, the t-statistics probability value of the EDUSMA variable in each equation is $0.0487,0.0162,0.0186$, and 0.000 . Since the probability value is less than 0.05 , the EDUSMA variable has a significant effect on the level of financial inclusion. The greater the percentage of adult population who finish high school education level, the greater the effect on increasing financial inclusion.

The findings from previous studies show that the level of education of the adult population has a significant and positive relationship with financial inclusion (Zinsdan Weil, 2016). Meanwhile, Allen et al. (2016) and Fungacova (2014) found that secondary school education affect several variables of financial inclusion such as opening a bank account. Park and Mercado (2015) confirmed that elementary school education level did not have any association with the increase in financial inclusion rate of developing countries in Asia.

c) Level of Income Inequality Variable

It was found from the study that income inequality does not have a significant impact on the financial inclusion. The t-statistical probability value of the INEQUALITY variable in each equation in sequence is $0.2218,0.2557$. 0.5919, and 0.899 , where the probability value is greater than alpha $5 \%$. This means that the variable INEQUALITY does not significantly influence the level of financial inclusion in Indonesia

d) Population Size Variable

The t-statistical probability value of the POP variable in each equation is 0.1037 , $0.5719,0.7628$, and 0.4554 , where the probability value is greater than alpha $5 \%$. This means that the POP variable does not significantly influence the level of financial inclusion in Indonesia. 
Among the reasons why the population size does not have a significant impact on financial inclusion is because the large number of people who are still living in rural areas which eventually exclude them from accessing financial services. The data by the Central Bureau of Statistics (BPS) shows that the majority of population mostly live in rural areas. In 2010,50.21\% of the Indonesian population live in rural areas, so it was unlikely to be targeted as a market share for financial products.

\section{e) Bank Branch Office Variable}

The probability value $t$ of the variable statistics of the bank branch office is less than the alpha value of $5 \%(0.0428)$. Therefore, it can be concluded that BRCH variable has a significant effect on the variation in the value of financial inclusion in Indonesia. Because the BRCH coefficient is positive, the more bank branch offices, the higher the value of financial inclusion in Indonesia.

Increasing the number of bank branches in various regions will expand the network of the bank, attract more customers, and improve access to financial services which will positively influence financial inclusion. Cakravarty and Pal (2013) discovered that the penetration of banking geography with the expansion of bank offices and ATMs as two policies that could be targeted to accelerate the increase in financial inclusion.

Based on the results of the study Allen et al. (2016) in its modeling estimates that the increase in bank branches and ATM penetration can increase financial inclusion. This is supported by a financial inclusion survey in Indonesia where one of the barriers to accessing financial services is the problem of long distances to use financial facilities.

With the ease of access to financial services, it will encourage people to access financial services related to service satisfaction perceived by the community.

\section{f) ATM Variables}

The probability variable of ATM is less than the alpha value of 5\% (0.0004), which means that the ATM variable has a significant effect on financial inclusion in Indonesia. Increasing ATM networks also encourages financial inclusion in Indonesia. This is because the existence of an increase in the availability of ATMs will enable the public to easily reach financial services without having to visit the bank's branch office. Through ATMs, people can already use financial services, this is closely related to the level of community satisfaction in accessing financial services that make it easier for the community.

\section{g) Cellular Phone Variable}

The probability value of the cellphone variable is 0.0001 , which signifies its strong and positive impact on the financial inclusion in Indonesia. The higher the usage of cell phone, the higher the financial inclusion level in Indonesia. In addition to the penetration of bank branch offices and ATMs, financial access via cellular phones that can be used even from non-android types of cellular phones is also very important to be followed up as other channels of expanding financial access.

With the upward trend of cellphone usage, it is expected that the banking industry could utilise this opportunity to increase financial inclusion in Indonesia. The use of mobile phones in the practice of offering financial services has been 
applied to several products such as mobile banking, which are expected to encourage broader expansion of financial services.

A study by Hannig And Jansen (2010) found that mobile phones are channels that can open up opportunities for the most basic financial services for the poor. The use of technology can drastically reduce production costs in real-time financial transactions, increase access points, reduce the use of cash and ultimately attract people who were previously classified as unbanked. In some countries, the use of mobile phones has proven to increase financial inclusion, as Philippine has launched a mobile payment service, estimating that it has 5.5 million users.

h) Internet Access Variables

Unlike the internet access which also significantly affects financial inclusion in Indonesia, but with a low significance level and the lowest coefficient value among other variables, statistically, the t-statistical probability value of the INTRNT variable is 0.0948 . With the $\mathrm{p}$-value of less than $10 \%$, this indicates that the INTRNT variable has a significant effect on the level of financial inclusion in Indonesia. With a positive coefficient value, it means that the direction of influence given by the INTRT variable to the level of financial inclusion is positive.

It is found that technological development in the financial sector in Indonesia has not been fully successfully implemented but is believed to help the country reaching its desired rate of financial inclusion. Because in some cases, virtual financial services is still incredibly risky which is associated with the high distrust of the public towards its usage. The low level of public internet literacy also supports the lack of applicability of the use of the internet as a path to increasing financial inclusion in Indonesia.

\section{CONCLUSION AND RECOMMENDATION}

\subsection{Conclusion}

It is evident from the study that the level of financial inclusion in Indonesia experienced an upward trend during the period of 2012-2015. On average, most of the provinces in Indonesia fall into the medium index of financial inclusion category and only 12 provinces in Indonesia are categorized in the high index of financial inclusion group. Most of the provinces in the Eastern Region of Indonesia have a relatively low level of financial inclusion.

Among the factors that have significant influence on financial inclusion in Indonesia is GDP per capita, educational level of the adult population, expansion of bank branch offices, number of ATM outlets, and the use of technology such as telephone use handhelds and the use of the internet as a new channel to distribute financial services products can accelerate the process of inclusion of financial services in Indonesia. Meanwhile, the following variables do not have significant effects on financial inclusion in Indonesia: junior high school education, income inequality, development of population size.

Income per capita variable is very influential on increasing financial inclusion in Indonesia. The higher the income of the community, the greater the ability of the community to reap the benefit of financial services. 
The level of public education is considered to be a determining factor of the community in considering the use of financial services in their economic activities along with the knowledge they possess. The level of education is possible to reflect people's knowledge of the use, benefits and influence of financial services on people's lives.

In addition, the variable 'accessibility as a supply of financial services to the community' is dominated by the spread of ATMs followed by the distribution of bank branch offices and the use of mobile phones and the internet. Penetration of banking infrastructure could potentially increase the acceleration of financial inclusion, because with the ease with which the public reaches financial services will motivate the public to use the services of the financial institutions.

Income inequality variable is found to not have any association with financial inclusion in developing countries because as we may well aware, income inequality in less-developed countries is considered as a major issue which is inseparable from financial inclusion.

Furthermore, it can be seen that Indonesia's level of inequality has increased over time while contrarily, financial inclusion has degraded. The is a contrast finding compares with the characteristics of Indonesia as a developing country which as previous research suggested, income inequality depends on economic development level of a country.

Based on the data by the Central Bureau of Statistics, the number of population living in rural areas is greater than those living in urban areas. Since the majority of financial services are available in urban areas, people living in rural become increasingly excluded from financial services.

\subsection{Recommendation}

The unequal distribution of financial services in various regions in Indonesia indicates that policy direction should be targeted by giving equal consideration to opportunities and opportunities for the entire region. For instance, paying more attention to eastern Indonesia, the most experienced lags in terms of financial service demand capability as well as the limited supply of financial services. Strengthening the ability of each individual is one of the principal issue in supporting the implementation of financial inclusion.

By improving the quality of life of the community through improvements in the level of education, especially education related to services provided by the financial sector, such as the introduction of financial products in formal institutions such as banking and encouraging increased income so as to increase the ability of the community to request financial services.

In addition, increasing the supply of financial services by improving financial infrastructure, especially the penetration of banking geography will greatly influence the increase in financial inclusion of all provinces in Indonesia.

Although this research has been able to uncover several issues related to financial inclusion, there are several limitations of the study. Firstly, the study lacks of a theory that can be used as an appropriate reference to explain the intervaraural influence. Secondly, there are still many pros and cons regarding the estimation results of variables that influence the increase in financial inclusion, and 
there are many other variables that may have a stronger influence on increasing financial inclusion but not included in this study. In addition, this study fails to explain how much the influence of each research variable on financial inclusion.

In addition, the results of the financial inclusion index from macro data show the pattern of financial inclusion index values between provinces in Indonesia still far from reality. As in the provinces in Papua, the macro data shows that Papua has a high financial inclusion level. However, the survey conducted by OJK classified Papua as the region with the lowest financial inclusion. It is therefore encouraged for future studies to utilise micro data and direct observation in terms of assessing financial inclusion in a region.

\section{REFERENCES}

ADBI-Institute. (2014). Financial Inclusion in Asia: Country Surveys. Asian Development Bank Institute. Retrieved November 23, 2017, from www.Adbi. org

Allen, Franklin, Demirguc-Kunt,A., L., Klapper, Maria Soledad Martinez Peria. (2016). The Fondation of Financial Inclusion; Understanding Ownership and Use of Formal Account. Journal Financial Intermediation, 27, 1-30. Retrieved October 18, 2017, from www.elsevier.com/locate/jfi

Bank Indonesia. (2014). Booklet Keuangan Inklusif. Departemen Pengembangan Akses Keuangan dan UMKM. Retrieved August 15, 2017, from www.bi.go.id

Chauvet, Lisa \& Jacolin, Luc. (2017). Financial Inclusion, Bank Consentration, and Firm Performance. World Development, 97, 1-13. Retrieved October 18, 2017, from www.Elsevier.Com/Locate/Worlddev

Chakravarty,Satya R., \& Pal, Rupayan. (2013). Financial Inclusion in India : An Axiomatic Approach. Journal of Policy Modeling, 35, 813-837. Retrieved October 18, 2017, from www.Elsevier.Com/Locate/Jpm

Demirgüç-Kunt, A., Córdova,Ernesto L., María Soledad \& Martínez Pería, Christopher Woodruff. (2011). Remittances and Banking Sector Breadth and Depth: Evidence from Mexico. Journal of Development Economics, 95, 229-241. Retrieved October 15, 2017, from www.elsevier.com/locate/devec

Demirgüç-Kunt, A., \& Klapper, L. (2013). Measuring Financial Inclusion: Explaining Variation in Use of Financial Services Across and Within Countries. Brookings Paper on Economic Activity, 44, 1 (Spring), 279-340. Retrieved October 18, 2017, from https://www.brookings.edu/wpcontent/uploads/2016/07/2013a_klapper. pdf

Fungacova, Zuzana \& Weill, Laurent. (2015). Understanding Financial Inclusion in China. Journal China Economic Review, 34, 196-206. Retrieved October 19, 2017, from http://Dx.Doi.Org/10/1016/J,Chieco.2014.12.004

Gabriella, Grace L., \& Goeltom, Miranda S. (2013). Pengaruh Pembangunan Keuangan Perbankan dan Akses Keuangan Perbankan Terhadap Kemiskinan di Indonesia. Retrieved November 22, 2017, from http://ib.ui.ac.id/naskahringkas/2015-08/ S44038-Laura\%20Grace\%20Gabriella

Hannig, A., \& S. Jansen. (2010). Financial Inclusion and Financial Stability: Current policy Issues. Adbi Working Paper 259. Tokyo: Asian Development Bank Institute. Retrieved October 18, 2017, from http://Www.Adbi.Org/ WorkingPaper/2010/12/21/4272.Financial.Inclusion.Stability.Policy.Issues/ 
Leyshon, A., \& Thrift, N. (1995). Geographies of Financial Exclusion: Financial Abandonment in Britain and the United State. Trans Inst. Br. Geogr, 20(3), 312-341.

Otoritas Jasa Keuangan. (2016). Statistik Perbankan Indonesia. Retrieved November 21, 2017, from www.ojk.go.id

Otoritas Jasa Keuangan. Data Perkembangan Indeks Inklusi Keuangan di Indonesia Tahun 2016. Retrieved November 11, 2017, from http://www.ojk.go.id/id/ berita-dan-kegiatan/siaran-pers

Park,Cyn-Young \& Mercado, Rogelio Jr. V. (2015). Financial Inclusion, Poverty, and Income Inequality in Developing Asia. Adb Economics Working Paper Series 426. Retrieved October 18, 2017, from www.adb.org.

Sarma, M. (2008). Index of Financial Inclusion. Indian Council for Research on International EconomicRelations Working Paper No. 215. Retrieved October 9, 2017, from icrier.org/pdf/Mandira\%20Sarma-Paper

Sarma, Mandira and Pais,Jesim.(2011).Financial Inclusion and Development:ACross Country Analysis. Journal of international development, 23, 613-628. Retrieved October 9, 2017, from www.researchgate.net/

Sarma, M. (2012). Index of Financial Inclusion - A Measure of Financial Sector Inclusiveness. Berlin Working Papers on Money, Finance, Trade and Development. Working paper No. 07/2012. Retrieved October 9, 2017, from finance-and-trade.htw-berlin.de

Wahyudi, S., Tri. (2016). Konsep dan Penerapan Ekonometrika Menggunakan Eviws. Raja Grafindo Persada; Jakarta.

World Bank. (2008). Finance for all: Policies and Pitfalls in Expanding Access. Policy Research Report, World Bank Washington DC. Retrieved October 18, 2017, from www.worldbank.org.id

World Bank. (2014). Global Financial Development Report ; Financial Inclusion. Green Press Intiative, Washington Dc. Retrieved October 18, 2017, from www. worldbank.Org/Financialdevelopment. 